\title{
PROJECT SUCCESS AND PROJECT TEAM INDIVIDUALS
}

\author{
Dr. Thomas M. Rogers \\ Western Carolina University, Cullowhee, USA
}

\begin{abstract}
Projects fail, and project managers are held responsible for these failures. This conceptual paper contends the cause of the success or failure of a project rests with the individuals who, in theory, comprise the project team. Research into project success or failure assumes a project team exists. This assumption deflects the need to look at the individuals who make up the team on which project managers depend for success. The lack of focus on these individuals undermines a project manager's need and desire of a cohesive team to perform the work for a project. This study exposes the gap in the project management literature about the impact on the success of a project of the individuals who comprise the project team. A series of questions give direction for future research on this topic.
\end{abstract}

Key words: commitment, individuals, projects, success, teams, trust.

\section{INTRODUCTION}

Whether a project succeeds or fails, we look to the project manager to bear the responsibility. The assignment of this responsibility (Ahadzie, 2014; Blaskovics, 2016; Muller, \& Turner, 2010) leads to the erroneous assumption that the project manager is solely responsible for the results of a project. The Project Management Book of Knowledge (PMBOK) (2016) and Le Roy and Fernandez (2015) indicate project managers rely on their project team to achieve the results of their project. Since the "team view . .. [focuses] on the means by which the deliverables are created" (Creasy, \& Anantatmula, 2013, p. 44), we must consider the individuals who populate a project team and the impact of these individuals on the results of a project. This research exposes the gap in the literature on the impact of the individuals who comprise the project team on project success.

\section{BACKGROUND}

The aim of any project manager is to successfully achieve the deliverables for their project on schedule and on budget. Project managers need teams to perform their projects. No one individual has all the skills necessary to successfully complete a project. The project manager must depend upon the individuals who are on the project team to apply their skills for a successful project. Yet, the project management literature tends to treat project teams as a single entity (e.g., Balagi, \& Murugaiyan, 2012; Blaskovics, 2016; Gehrig, 2007; Muller, \& Turner, 2010). Some research discusses how to identify the appropriate skills for a project manager (Hwang, \& Ng, 2013) and how to choose the individuals to best achieve success for projects (Baykasoglu, Dereli, \& Das, 2007; Chan, Scott, \& Chan, 2004; Loo, 2003). Once chosen, however, the silence about addressing the needs of these individuals on these teams exposes the assumption that they area coherent team of individuals focused and committed to a common goal while holding each other mutually accountable (Katzenbach, \& Smith, 1993). Oddly, the application of these elements leads to the ignoring of the individuals who comprise the team. Project managers, however, ignore the individuals who comprise the team at their own peril because these individuals perform the tasks necessary to complete a project. These individuals create the success or failure of projects for which we hold project managers responsible.

A look at the extent of project failures will help us understand the importance of this topic. The Project Management Institute (PMI) (2017), the Standish Group 
(VitalityChicago, 2017), and KPMG (PapkeShields, Beise, \& Quan, 2010) show the scale of projects failing to meet the original scope, budget, or schedule (See Figure 1).

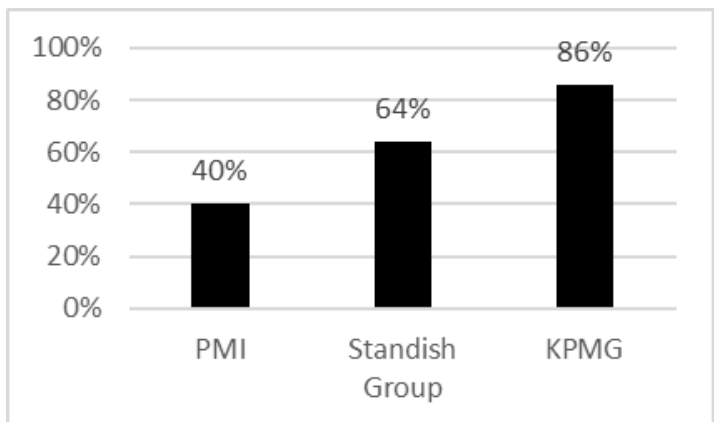

Figure 1: Project Failures

The Project Management Institute (2017) reported that over 40 percent of project fail to meet their original scope and budget. Sixtyfour percent of projects studied by the Standish Group (VitalityChicago, 2017) and 86 percent studied by KPMG (Papke-Shields et al., 2010) failed to meet their original scope, budget, or schedule. The Standish Group also found that less than half (42\%) of projects using the Agile approach were successful in achieving scope, budget, and schedule requirements while less than a third (26\%) of those employing the Waterfall approach for managing a project were successful (VitalityChicago, 2017). Further, 58 percent of projects using the Agile approach and 74 percent of projects using the Waterfall approach were challenged or failed (VitalityChicago, 2017).

These approaches rely on project teams and the individuals who populate them. Therefore, regardless of approach, project managers must look to and work with the individuals on the project team to achieve project success.

\section{LITERATURE REVIEW}

As a key stakeholder in any project, the top management team should drive the connection between a corporate strategy and a project to provide the basis for the clear definition of the purpose, objectives, and criteria for the success of a project (Cleland, 1995; Fedor, Gosh, Caldwell, Maurer, \& Singhal, 2003; Mullaly, 2004; Schultz, Slevin, \& Pinto, 1987; and Thite, 1999). This connection drives the firm's commitment of resources (money, material, and people) for a project and will support the project when the inevitable changes occur during the life of a project (Fedor, et al., 2003; Schultz, et al., 1987; Thamhain, 2004; Thite, 1999).The greater the agreement between top management, project managers, and end users, the greater the probability of project success (Wateridge, 1998).

"Meeting the actual needs of stakeholders is the most important criterion in defining project success" (Anantatmula, \& Rad, 2018, p. 166). Ojiako, Johansen, and Greenwood (2008) found that companies must use projects to meet their strategy objectives, but project success factors may vary from project to project. Chua, Kog, and Loh (1999) found that project success factors range from adequacy of plans to project manager competency to risk identification. These studies focus on process, the project manager, and the alignment between the project manager and the end user, but they assume the commitment and cooperation of individuals to the project team and, hence, project success. These studies illustrate the lack of focus on the project team. "[T] he success of the project would include success of the implementation team in crafting the deliverable" (Creasy, \& Anantatmula, 2013, p. 45). Identifying this key success factor, however, still, assumes a project team exists and further assumes the individuals assigned to a team will commit to the team.

Mullaly (2004) and Thamhain (2004) found that the human side of project management drives team performance. The human side is the individuals who make up the project team, but these individuals are challenged because "some of the project team members are engaged in more than one project" (Anantatmula, 2008, p. 35). This situation means project managers must consider what success looks like for a potentially distracted project team (Anantatmula, \& Rad, 2018; Judgev, \& Muller, 2005). By design, project managers rely on the individuals on their project teams to perform the tasks deliverables, and it is the success of these individuals that determines the success of a project and, therefore, deserves greater focus. Figure 2 will help us see "the woods for the 
trees" (Harvey, 2010, p. 26). The current state of research assumes the project team exists and flows from the project manager and his or her approach to the project. The future state in Figure 2 shows that the individuals who populate the project team sit in opposition to, but in coordination with, project managers and the approach they apply to the project. It is this opposition that highlights the need to correctly assign the responsibility for the success or failure of a project. Placing the burden of failure on the project manager or on the approach to project management assumes that the individuals assigned to a project team see the value and are willing to invest their agency to the team. Before assigning the responsibility for project failure to the project manager, we should determine if the identified individuals commit to the project team.

Current State

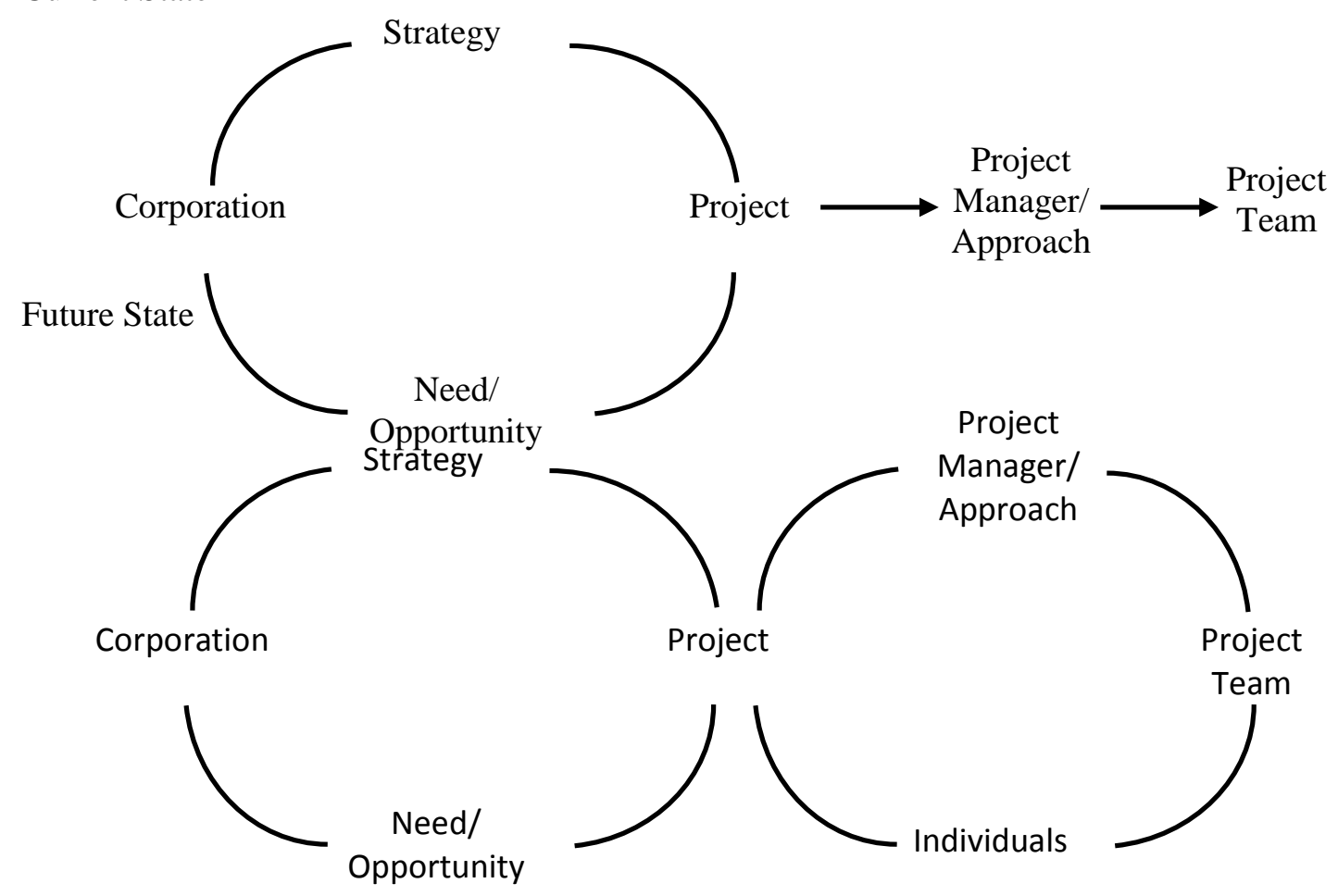

Figure 2: Current and Future States of Individuals on a Project Team

Each "team" functions under conditions which impact how they will cooperate. (Rogers, 2014). The Project Management Book of Knowledge (PMBOK) defines a project team as "a set of individuals who support the project manager in performing the work of the project to achieve its objectives" (PMBOK, 2016, p. 717). As you might expect, this definition places support of the project manager as the focus of this "set of individuals" and assumes this set of individuals is a team that will trust their project manager. Nielsen (2004) indicates, however, that trust in the project manager does not directly correlate to project success.
Katzenbach and Smith provide a more generic but more granular definition of a team: "A team is a small number of people with complementary skills who are committed to a common purpose, performance goals, and approach for which they hold themselves mutually accountable" (Katzenbach, \& Smith, 1993, p. 45). Project managers applying this definition assume these elements are present and, therefore, a team exists. Assuming a team exists deflects the needed attention and care necessary for the individuals working on the project to commit their agency to the team and, hence, the project. 


\section{ASSIGNMENT OF AGENCY}

Each person brings his or her own agency, or self-interest, to a relationship. The weight of the agency of the relationship between people requires consideration when working with a team. The definition of success of the relationship must serve the needs of the project as well as appeal to the self-interest of the individuals on the project team. For an individual to fully commit his or her agency to a project, the project must provide some value to the individual. If the project scope is well defined, Katzenbach and Smith's (1993) common goal will exist for a project. The common goal from the project scope serves as the basis for orienting the people on the project team to achieve the deliverable of the project. The clear scope is the starting point for an individual to determine the value of a project for him or herself and is a necessary element for individuals to bind together as a project team.

Without a proper orientation as to the purpose and scope of the project, the individuals will not have any basis for trust. Trust is another necessary element for a group of people to have the opportunity to form a team (Katzenbach, \& Smith, 1993). If the project manager assembles and supports the people with the right mix of skills to achieve the goal of the project, as implied by the PMI definition (PMI, 2016), these individuals may well trust the project manager and the ability of other individuals on the team to perform the project. The common goal of the project and the trust in one another's abilities does not, however, mean that the individuals will commit to the team or be willing to be held accountable by their project manager or the other individuals assigned to the team.

For PMI (2016) and Katzenbach and Smith (1993),trust is a proxy for commitment. While trust promotes collaboration among team members (Ring, 1996), "no direct relation [is found] between establishing trust and managing outcomes" (Anantatmula, 2008, p. 42) for a project. Trust is necessary for clarifying roles for team members and identifying how their roles complement each other. Trust, also, opens the path for people to work together to examine, question, and make clear the purpose and objective for a project. Trust, however, does not equal commitment even though individuals may give lip service to commitment to a team or project. True commitment won't occur until the individual sees value they will gain by investing their agency in the project team.

\section{DISCUSSION}

The focus on the project manager in the project management literature is understandable given the pivotal role of the project manager as the primary interface between project stakeholders and the project team. The importance of the project manager increases due to the delegation of authority from the project stakeholders, in particular the project sponsor, to lead the project. Recognition of the key role played by the project manager leads to numerous studies focused on what makes a good project manager (e.g., Anantatmula, 2010; Berssaneti, \& Carvalho, 2015; Dolfi, \& Andrews, 2007; Pinto, \& Slevin, 1987).

Despite these numerous studies about who and what makes a good project manager, the election process for choosing a person to serve as a project manager may leave something to be desired. "[M] ost organizations . . . draft a technician or administrator with a good reputation with the organization to lead the project . . . [thus, creating] "project managers by accident" (Gehrig, 2007, p. 50). It is difficult for an accidental project manager to be the transformative leader reflected in the works of Leban and Zulauf (2004), Keller (1995), or Thite (1999). As "attention should be given to project managers on an individual basis," (Creasy, \& Anantatmula, 2013, p. 46), so must we give attention to the individuals on the project team. Therefore, new (and, perhaps, old) project managers should receive "training, coaching, and problem resolution" (Creasy, \& Anantatmula, 2013, p. 46) to help them build the trust as suggested by PMI's (2016) definition of a team and the commitment and mutual accountability as described by Katzenbach and Smith (1993). If selection of the project manager can occur in such a haphazard manner, no one can reasonably expect an individual to trust the 
ability of the project manager. Arbitrary promotion of someone to project manager forces him or her to scramble to learn how to be a project manager. This focus on becoming a project manager means that he or she cannot build the trust of the project team or the commitment of the individuals on a project team. This focus forces project managers to assume all elements are present and that a project team exists which negates the need to even look to see if these individuals have coalesced into a team. If a project manager does not look to see if he or she has a team, then there is no need for them to spend time considering the individuals who comprise the "team".

\section{CONCLUSION}

This research exposes the tendencies in the literature to focus on the project manager, treat the project team as a single entity, and ignore the individuals who comprise the project team. Debate continues within the project management literature (e.g., Balagi, \& Murugaiyan, 2012; Hajjdiab, \& Taleb, 2011) as to whether Waterfall or Agile is the better approach for achieving project success. This level of debate tends to ignore the fundamental necessity of the project team and the individuals who populate them for project success. These individuals perform the tasks to complete work packages to build project deliverables. Without these individuals successfully completing their assigned tasks, no project can succeed.

For a team to perform a project successfully, the project sponsor and the project manager must prove the value of working on the project to the individuals of the project team. This acknowledgement of each individual requires establishing value for the individual before he or she will invest their agency and commit to the project team. Given that projects, often, fail because of people-related issues and lack of commitment (Kerzner, 2006), more attention needs to be paid to the people performing the tasks for a project. Trust, commitment, and mutual accountability (Katzenbach, \& Smith, 1993) cannot occur within a project team without identifying value for the individuals who comprise it.

\section{FUTURE RESEARCH}

This gap in the literature of project success leaves us with a series of questions.

- What is the business value of caring for/investing in the individuals on a project team?

Quantitative and case research is needed to determine if the time, effort, and cost of caring for and investing in the individuals on the project team generate a positive value for the business. If these actions do not generate a positive return, then the business should stop pursuing them (El-Halwagi, 2017; GuillenCuevas et al., 2018).

- What is the impact of the agency of the individual on how project managers choose team members?

Research is needed for project managers to better understand the motivation of individuals so that a firm can make a more robust and informed choice for project team members than, just, they possess a skill needed for a project. Ideally, a company chooses a person to serve on a project team based on the skills necessary to perform the tasks on a project, and individuals choose to join a project team based on the benefits and value they perceive comes from serving on the project team. Recognizing project teams are not a faceless group with a single identity forces the consideration of the self-interest of these individuals. This self-interest is the agency each individual holds and represents the value each individual believes he or she can contribute to the success of any endeavor. The value they can deliver will drive how individuals believe a company should reward them for their service on a project team.

- How does a company convince individuals to commit their agency to a project team and the success of a project?

Research is needed into how companies can determine an individual's self-interest. Each individual has a vested interest in the success of their own career. Understanding this selfinterest allows companies to better align the needs of individuals with the needs of a project. The company can leverage this knowledge to convince individuals to commit 
to a project team and increase the probability of project success.

The answers to these questions will provide project managers with a solid basis for attracting individuals who will commit to their project teams and generate a higher probability for project success.

\section{REFERENCES}

Ahadzie, D. (2014). Competencies Required of Project Managers at the Design Phase of Mass House Building Projects, International Journal of Project Management, 32(6), 958-969.

Anantatmula, V. (2010). Project Manager Leadership Role in Improving Project Performance, Engineering Management Journal, 22(1), 13-22.

Anantatmula, V. (2008). The role of technology in project manager maturity model, Project Management Journal, 39(1), 34-48.

Anantatmula, V., \& Rad, P. (2018). Role of Organizational Project Management Maturity Factors on Project Success, Engineering Management Journal, 30(3), 165-178.

Balagi, S., \& Murugaiyan, M. (2012). Waterfall Vs V-Model Vs Agile: A Comparative Study on SDLC. International Journal of Information Technology and Business Management, 2(1), 26-30.

Baykasoglu, A., Dereli, T., \& Das, S. (2007). Project team selection using fuzzy optimization approach, Cybernetics and Systems, 38(2).

Berssaneti, R., \& Carvalho, M. (2015). Identification of variables that impact project success in Brazilian companies. International Journal of Project Management, 33(3), 638-649.

Blaskovics, B. (2016). The impact of project manager on project success-The case of ICT sector. Society and Economy, 38(2), 261-281.

Chan, A., Scott, D., \& Chan, A. (2004). Factors affecting the success of a construction project, Journal of Construction Engineering and Management, 130(1), 153-155.
Chua, D. K. H., Kog, Y. C., \& Loh, P. L. (1999). Critical success factors for different project objectives. Journal of construction Engineering and Management, 125(3), 142-150.

Cleland, D. (1995). Leadership and the project management body of knowledge. International Journal of Project Management, 13(2), 83-88.

Creasy, T., \& Anantatmula, V. (2013). From Every Direction-How Personality Traits and dimensions of project Managers Can Conceptually Affect Project Success, Project Management Journal, 44(6), 3651.

Dolfi, J., \& Andrews, E. (2007). The subliminal characteristics of project managers: An exploratory study of optimism covering challenge in the project management work environment, International Journal of Project Management, 25, 674-682.

El-Halwagi, M. (2017). A return on investment metric for incorporating sustainability in process integration and improvement projects, Clean Technologies \& Environmental Policy, 19(2), 611-617.

Fedor, D. B., Gosh, S., Caldwell, S. D., Maurer, T. J., \& Singhal, V. R. (2003). The effects of knowledge management on team members' ratings of project success and impact. Decision Sciences, 34(3), 513-539.

Gehrig, D. R. (2007). Applying traits of leadership to project management. Project Management Journal, 38(1), 4454.

Guillen-Cuevas, K., Ortiz-Espinoza, A., Ozinan, E., Jimenez-Gutierrez, A., Kazantzis, N., \& El-Halwagi, M. (2018). Incorporation of safety and sustainability in conceptual design via a return on investment metric, ACS Sustainable Chemistry \& Engineering, 6(1), 14111416.

Hajjdiab, H., \& Taleb, A. (2011). Adopting agile software development: Issues and challenges, International Journal of Managing Value and Supply Chains, 2(3), 1-10.

Harvey, D. (2010). A Companion to Marx's Capital. Verso: London. 
Hwang, B., \& Ng, W. (2013). Project management knowledge and skills for green construction: Overcoming challenges, International Journal of Project Management, 31(2), 272-284.

Judgev, K., \& Muller, R. (2005). A retrospective look at our evolving understanding of project success, Project Management Journal, 36(4), 19-31.

Katzenbach, J. R., \& Smith, D. K. (1993). The Wisdom of Teams. Boston: Harvard Business School Press

Keller, R. T. (1995). 'Transformational' leaders make a difference. Research Technology Management, 38(3), 41-44.

Kerzner, H. (2006). Project management: A systems approach to planning, scheduling, and controlling (9th ed.), New York: Wiley.

Leban, W., \& Zulauf, C. (2004). Linking emotional intelligence abilities and transformational leadership styles. Leadership\& Organizational Development Journal, 25(7/8), 583-591.

Le Roy, F., \& Fernandez, A. (2015). Managing coopetitive tensions at the working-group level: The rise of the coopetitive project team, British Journal of Management, 26(4), 671-688.

Loo, R. (2003). Assessing "team climate" in project teams, International Journal of Project Management, 21(7), 511-517.

Mullaly, M. E. (2004). PM success in organizations, trends, best practices and next steps. Proceedings of the $18^{\text {th }}$ IPMA Global Congress 2004, Moscow.

Muller, R., \& Turner, R. (2010). Leadership competency profiles of successful project managers, International Journal of Project Management, 28(6), 437-448.

Nielsen, B. (2004). The role of trust in collaborative relationships: A multidimensional approach. Management, 7(3), 239-256.

Ojiako, U., Johansen, E., \& Greenwood, D. (2008). A qualitative re-construction of project measurement criteria, Industrial Management \& Data Systems, 108(3), 405-417.

Papke-Shields, K., Beise, C., \& Quan, J. (2010). Do project managers practice what they preach, and does it matter to project success? International Journal of Project Management, 28(7), 650-662.

Pinto, J. K., \& Slevin, D. P. (1987). Critical factors in successful project implementation, IEEE Transactions on Engineering Management, 34, 22-27.

Project Management Institute. (2016). Project Management Book of Knowledge (PMBOK) $\left(6^{\text {th }}\right.$ ed). Newtown Square: Project Management Institute.

Project Management Institute. (2017). Pulse of the Profession: Success Rates Rise Transforming the High Cost of Low Performance. Newtown Square: Project Management Institute.

Ring, P. (1996). Fragile and resilient trust and their roles in economic exchange, Business \& Society, 35(2), 148-175.

Rogers, T. (2014). Is it a team? A working group? Or just a co-located collection of people? Paper presented at PMI® Global Congress 2014-North America, Phoenix, AZ. Newtown Square, PA: Project Management Institute.

Schultz, R. L., Slevin, D. P., \& Pinto, J. K. (1987). Strategy and tactics in a process model of project implementation. Interfaces: Institute of Management Sciences, 17(3), 34-46.

Stanford Group, (2009) 2009 CHAOS Study, http://theproductivityhabit.wordpress.co $\mathrm{m} / 2009 / 05 / 12 /$ standish-chaos-report2009-are-projects-failing-or-are-projectmanagers-failing/

Thamhain, H. (2004). Leading technologybased project teams. Engineering Management Journal, 16(2), 36-42.

Thite, M. (1999). Leadership: A critical success factor in IT project management, technology and innovation management. Proceedings of the Portland International Conference on Management and Technology (PICMET), 2, 298-303.

VitalityChicago.com, (2017).https://vitalitychicago.com/blog/a gile-projects-are-more-successfultraditional-projects/ accessed March 20, 2019.

Wateridge, J. (1998). How can IS/IT projects be measured for success?. International Journal of Project Management, 16(1), 59-63. 